Vol 1, No 2 Agustus - Desember 2020

\title{
PRANATA SOSIAL, BUDAYA HUKUM DALAM PERSPEKTIF SOSIOLOGI HUKUM
}

\author{
Halida Zia, Nirmala Sari, Ade Vicky Erlita \\ Dosen dan mahasiswa pada Fakultas Hukum Universitas Muara Bungo \\ Jl. Diponegoro No. 27 Kelurahan Cadika, Kecamatan Rimbo Tengah, \\ Kabupaten Bungo Telp/Fax (0747) 323310 Kode Pos 37214 \\ E-mail :umb101016@gmail.com halidazia621@yahoo.co.id
}

\section{RINGKASAN}

Sosiologi berasal dari kata yunani yaitu sosio masyarakat dan logos (ilmu) yang artinya ilmu yang mempelajari masyarakat atau dinamika masyarakat, hak dan kewajiban masyarakat atau pranata sosial hukum mengatur masyarakat. Sosiologi adalah ilmu yang mempelajari tentang hubungan timbal balik dan seluruh kaidah baik struktur sosial, pranata sosial,kelompok sosial yang ada dalam kehidupan masyarakat.sosiologi merupakan suatu ilmu sosial yang murni dan bukan merupakan ilmu pengetahuan terapan. Induk dari ilmu pengetahuan adalah filsafat. Filsafat adalah bagaimana seorang filsuf mencari sebuah kebenaran yang di rumuskan melalui teori.filsuf menemukan gejala-gejala terhadap sesuatu pada saat perenungan. Filsafat mengakaji ilmu sosial dan ilmu alam.

Kata kunci: Pranata sosial, budaya hukum, sosiologi

\section{PENDAHULUAN}

Sosiologi berasal dari kata yunani yaitu sosio masyarakat dan logos (ilmu) yang artinya ilmu yang mempelajari masyarakat atau dinamika masyarakat, hak dan kewajiban masyarakat atau pranata sosial hukum mengatur masyarakat.

Sosiologi adalah ilmu yang mempelajari tentang hubungan timbal balik dan seluruh kaidah baik struktur sosial, pranata sosial,kelompok sosial yang ada dalam kehidupan masyarakat.sosiologi merupakan suatu ilmu sosial yang murni dan bukan merupakan ilmu pengetahuan terapan.

Induk dari ilmu pengetahuan adalah filsafat. Filsafat adalah bagaimana seorang filsuf mencari sebuah kebenaran yang di rumuskan melalui teori.filsuf menemukan gejala-gejala terhadap sesuatu pada saat perenungan. Filsafat mengakaji ilmu sosial dan ilmu alam. Seorang filsuf yunani menyatakan bahwa induk dari ilmu pengetahuan adalah filsafat. Filsuf adalah seorang yang merencana, menemukan ilmu pengetahuan, dan menemukan sebuah teori yang skala dunia. Salah satu ilmuan terkenal aristoteles menyatakan dalam teorinya bahwa manusia adalah makhluk sosial, manusia tidak bisa hidup sendiri, manusia cenderung hidup berkelompok.

Proses seorang manusia berawal dari seorang bayi pada saat itu manusia hanya berinteraksi dengan ibunya saja.kemudian tumbuh besar sedikit, dia berkomunikasi dengan saudara-saudara dengan keluarga.kemudian setelah memasuki pendidikan formal, di sekolah, berinteraksi dengan teman-teman, dengan guru, dengan lingkungan sosial lainnya. Dan sampai manusia mati maka manusia tersebut tidak bisa hidup sendiri manusia tersebut membutuhkan orang lain untuk membantu dirinya.

Hukum timbul karena adanya kepentingan satu dengan kepentingan 
lainnya.ketika interaksi sosial jalani, maka akan adanya benturan, pergesekan, dan ketidakharmonisan antara masyarakat satu dengan masyarakat yang lainnya.hukum hadir untuk untuk menjawab permasalahan-permasalahan masyarakat.

Sosiologi adalah ilmu yang mempelajari tentang hubungan timbal balik dan seluruh kaidah baik struktur sosial,pranata sosial, kelompok soisal yang ada dalam kehidupan masyarakat.

Fakta mengenai sosiologi menurut selo soemarjan:

1. sosiologi merupakan ilmu sosial dan bukan merupakan ilmu pengetahuan alam atau ilmu kerohanian

2. sosiologi bukan merupakan disiplin yang normative, akan tetapi adalah suatu disiplin yang kategoris

3. sosiologi merupan ilmu pengetahuan yang murni bukan merupakan ilmu pengetahuan terapan

Konsep dari sosiologi hukum sebagai sarana sosial kontrol atau pengendali sosial di dalam kehidupan bermasyarakat yaitu hukum memberikan rasa aman, membersihkan rasa damai kepada masyarakat. Dan hukum dapat mengcontrol kehidupan masyarakat agar menjadian masyarakat yang madani, masyarakat yang beradab.ketika masyarakat melakukan pelanggaran maka masyarakat tersebut akan berurusan dengan hukum. Masyarakat yang melakukan pelangaran idealnya akan dibina, dibentuk dan diukur dari seberapa besar pelangaran yang ia langgar sesuai dengan hukum yang berlaku.

Fungsi hukum:

1. Berfungsi secara filosofis yaitu masyarakat berharap hukum sebagai keadilan,kemanfaatan, ketertiban maupun kesejahteraan.
2. Berfungsi secara sosiologis yaitu masyarakat harus mematuhi hukum dimana hukum itu berlaku

3. Berfungsi secara yuris yaitu peraturan yang merupakan bagian dari suatu kaidah hukum

Tujuan hukum adalah untuk memberikan kepastian hukum kepada masyarakat dalam kehidupan, karena di dalam masyarakt terdapat gejala-gejala sosial yang harus di control melalaui hukum yang berlaku. Dan hukum di buat untuk menjadikan masyarakat yang lebih mengerti pengetahuan akan hukum yang ada.

\section{PERMASALAHAN}

Bagaimana Pranata Sosial, Budaya Hukum Dalam Perspektif Sosiologi Hukum?

\section{PEMBAHASAN}

\section{Pranata Sosial}

Pranata adalah seperangkat norma-norma yang diatur di dalam masyarakat agar tidak terjadi penyimpangan, pelanggaran, atau perbuatan-perbuatan yang menjadi keresahan di dalam bermasyarakat. Menurut koentjaraningrat pranata sosial adalah suatu system tata kelakuan dan hubungan yang terpusat pada aktifitas dalam masyarakat. Seseorang di katakana masuk dalam suatu lingkungan sosial yaitu mereka diperlakukan terikat oleh seperangkat aturan yang berlaku di lingkungan tersebut sesuai dengan kedudukan atau status ataupun perannya.

- Contoh di lingkungan rumah seorang yang berkedudukan sebagai kepala keluarga yang dalam suatu keluarga ayah terbiasa dibuatkan sarapan istrinya kemudian anak-anaknya hormat apapun yang dikatakan oleh ayah. Ayah juga bertindak selaku kepala keluarga yang memiliki peran 
Vol 1, No 2 Agustus - Desember 2020

untuk mewakili keluarga untuk ke berurusan dengan pihak luar.

- Contoh di lingkungan kuliah. Seorang mahasiswa yang terikat di dalam peraturan yang dibuat universitas yang harus mengikuti ujian tengah semester,ujian semester dan mengikuti kkn, mengikuti magang, dan lain-lain. Jadi ketika mahasiswa masuk di fakultas hukum, artinya aturan yang berlaku di universitas, mahasiswa harus mematuhi.

Ketika masuk pada lingkungan tertentu, masyarakat diikat dengan aturan yang berlaku di manapun ia berada.

Tiga kata kunci perangkat sosial:

1. Yang pertama ada nilai dan normal sosial,

2. Kedua pola perilaku yang diberlakukan yang menjadi prosedur umum yang

3. Ketiga sistem hubungan, yaitu peran seorang individu di dalam masyarakat.

Nilai dan norma mengatur tentang apa yang boleh dan tidak boleh dilakukan.nilai dan norma menjadi acuan atau pegangan masyarakat untuk mematuhi hukum yang berlaku agar tidak terjadi penyimpangan.

- Contoh kepala adat atau orang yang dianggap dituakan di suatu dusun memiliki aturan yang harus dipatuhi oleh seluruh masyarakat dusun tersebut.jika masyarat tidak patuh maka masyarakat tersebut akan di kucilkan atau bahkan di berikan sanksi untuk membuat efek jera kepada masyarakat yang melanggar aturan adat tersebut.

Pola perilaku sesuai dengan prosedur umum yang tidak melakukan hal-hal yang mengganggu ketertiban umum seperti mencuri. Atau melakukan pelanggaran- pelanggaran lainnya. Peran dari individu masyarakat sesuai dengan aturan yang dibuat oleh masyarakat setempat.

Fungsi dari pranata sosial ini di dalam masyarakat:

1. Memberikan pedoman pada anggota masyarakat tentang bagaimana bertingkah laku atau bersikap di dalam usaha memenuhi kehidupannya dalam sehari, kesehari-hariannya. Fungsi dari pranata sosial adalah menjaga keutuhan di masyarakat.Kehidupan bermasyarakat banyak timbul gejolak ataupun timbul konflik, pertikaian dan pertentangan yang berbeda.

- Contoh di dalam suatu dusun gitu terdiri dari orang-orang masyarakat yang dalam memenuhi kebutuhannya sehari-hari secara adil dan memadai. Sehingga potensi-potensi konflik tersebut tidak terjadi.

2. Berfungsi untuk memberikan pegangan dalam melakukan pengendalian sosial (sosial control) sanksi-sanksi atas pelanggaran normanorma sosial tersebut merupakan sarana agar setiap masyarakat melakukan pengendalian sosial.

- Contoh di dalam suatu dusun terdapat sepasang kekasih yang melakukan hal-hal yang tidak senonoh maka sepasang kekasih tersebut akan mendapatkan sanksi atas perbuatannya.hal tersebut di lakukan oleh ketua adat agar masyarakat lainnya tidak melakukan hal serupa.

Dengan adanya hubungan timbal balik antar masyarakat maka pranata sosial di dalam kehidupan bermasyarakat dapat menjadi upaya preventif untuk mencegah terjadinyakonflik di tengah-tengah masyarakat. 
Ketika norma, atau dalam interaksi sosial tidak diindahkan, maka hukum hadir dengan sanksi yang lebih tegas dan nyata untuk mewujudkan keadilan. Agar terwujudnya masyarakat madani, masyarakat yang beradab.

Pengendali sosial terdiri dari :

1. Pengendalian sosial bersifat preventif artinya suatu usaha sebelum terjadinya ganguan pada masyarakat

- Contoh : penyuluhan terhadap bahanya narkoba di sekolahsekolah agar siswa terhindar dari bahaya narkoba

2. Pengendalian sosial bersifat represifartinya pengendalian setelah kejadian.

- Contoh: seorang pencuri yang telah melakukan pencurian kemudian tertangkap oleh polisi dan di kenakan sanksi kepada pencuri tersebut untuk memberikan efek jera kepada pencuri tersebut.

\section{Hukum Dan Masyarakat}

Menurut Auguste Comte sosiologi merupakan ilmu pengetahuan yang mempelajari manusia sebagai makhluk yang senantiasa hidup bersama dengan sesame.

Manusia sebagi makhluk sosial adalah manusia yang hidup dengan manusia lainnya.manusia akan membutuhkan manusia selain dirinya. Hubungan timbale balik antar masyarakat akan menimbulkan hak dan kewajiban antar individu dengan individu, kelompok dengan kelompok dan masyarakat yang satu dengan masyarakat lainnya.hukum sebagai kaidah mengatur pola perilaku masyarakat. Faktor penyebab masyarakat ematuhi hukum :

Kepentingan masyarakat yang terlindungi oleh hukum

Orang akan mematuhi hukum karena suatu imbalan untuk menghindarkan diri dari sanksi yang di jatuhkan jika hukum di langgar
Manusia akan memelihara hubungan yang baik dengan par anggota masyarakat lainnya. Manusia patuh karena kaidahkaidah hukum sesuai dengan nilai-nilai yang menjadi pegangan masyarakat Kesadaran hukum merupakan pandangan masyarakat tentang hukum, apa yang boleh dan tidak boleh di lakukan oleh masyarakat. Fungsi hukum yaitu sebagai pengendali kehidupan masyarakat untuk menetapkan tingkah laku masyarakat yang dianggap menyimpang dan sanksi atau tindakanyang dilakukan oleh hukum. Hukum sebagi alat untuk mengubah masyarakat menjadi masyarakat yang tertib,

\section{Budaya Hukum}

Menurut Lawrence M. Friedman dalam system hukum terdiri dari 3 sub:

1. Legal capture yaitu aparatur atau lembaga, contoh kepolisian, kejaksaan, dan pengadilan.

2. Legal substance yaitu peraturan perundang-undangan

3. Legal cultute yaitu budaya hukum.

Tujuan hukum ada tiga:

1. Memberikan kepastian hukum.

2. Memberikan rasa keadilan.

3. Memberikan kemanfaatan.

Tujuan hukum akan terwujud jika :

1. Aparatur negara polisi, jaksa, hakim di dalam memproses suatu perkara sesuai dengan peraturan perundangundangan yang berlaku.

2. Substansinya yaitu undang-undang misalnya tindak pidana korupsi, undang-undang tentang narkotika.

3. Budaya hukum ini sangat-sangat berpengaruh

Hukum tidak mencerminkan keadilan jika terjadi ketidaksingkron antara struktur, substansi dan budayanya.

Menurut jimly assidiqy mengatakan bahwa di dalam bukunya, pembudayaan 
atau pemasyarakatan dalam pendidikan hukum, itu sering, tidak penting di dalam kehidupan upaya menegakkan hukum di indonesia. Karena lebih mengedepankan pada substansi.

Analogi di dalam struktur hukum:

1. Budaya itu diibaratkan mesin jadi struktur itu struktur hukum.

2. Struktur diibaratkan mesin yang menghasilkan sesuatu. Substansi diibaratkan dari yang dihasilkan oleh mesin.

3. Budaya merupakan apa saja dan siapa saja yang memutuskan dan menjalankan mesin tersebut dan menggunakan untuk membatasi penggunaan mesin.

Pembudayaan di indonesia untuk mengendalikannya budaya-budaya hukum yang buruk belum mendapat perhatian yang sangat besar disbanding struktural sama substansinya padahal pada dasarnya budaya tuh sangat-sangat penting.

Hubungan hukum dan budaya tidak dapat dielakkan karena hukum yang dibuat dengan sebaik-baiknya tidak akan berfungsi apabila budaya masyarakat cenderung tidak mengindahkan peraturan yang seharusnya di patuhi.peraturan yang di buat mengacu pada system nilai yang filosofis agar setiap garis kebijakan dan aturan hukum yang tercipta dinilai akomodatif dan responsive terhadap aspirasi masyarakat yang adil.

Hubungan hukum dan budaya sangat erat kolerasinya.hukum yang bagus yang dibuat itu kalau budayanya tidak bagus.rangkaian dari penerapan seperangkat hukum tersebut ditentukan baik atau buruk buruknya budaya di suatu masyarakat yang akan menjadiakan hukum tersebut hidup atau tidaknya di dalam masyarakat.

Upaya pembudayaan dan kecerdasan hukum masyarakat sebagai berikut :

1. Upaya pembudayaan hukum harus di lakukan dengan metode yang tepat
2. Sosialisasi berbagai materi hukum

3. Budaya hukum masyarakat harus di bagun parallel

4. Pembudayaan hukum di lakukan harus sejak usia dini

Ciri masyarakat yang cerdas dan berbudaya hukum adalah masyarakat yang memahami hukum secara komprehensif yang terkait dengan hak dan kewajibannya.

Adanya ketimpangan antara das soland dan dasen, dasoland, dan dasen adanya ketimpangan antara yang dicita-citakan atau yang harapkan dengan yang terjadi di lapangan. Ketimpangan antara dasen dan dasen hukum yang seharusnya yang dibuat yang sifatnya substansi adalah hukum yang dicita-citakan seperti kuhp berarti kalau mencuri ada sanksi, membunuh ada sanksi. Jadi kalau penerapannya kembali lagi ke struktur kepada budaya. Mengendalikan budaya hukum supaya bagus dan supaya tercapai tujuan hukum karena harmonisasi antara substansi yang diperbaiki.

- Contoh masyarakat di indonesia berbagai macam suku, berbagai macam bahasa, budaya. Dari indonesia, sabang sampai merauke. Dan tidak semua memahami hukum.masyarakat kota dengan masyarakat desa pemahaman mereka terhadap hukum cenderung berbeda. Untuk di masyarakat kota, masyarakatnya lebih terbuka dan modernisasi. Dengan adanya harmonisasi, adanya sosialisasi kepada masyarakat di dusun ataupun kota tentang kalau melakukan sesuatu maka akan adanya pelanggaran. Kalau melakuan suatu tindakan ini akan terjadi penyimpangan, akan terjadi keresahan di masyarakat. Dengan adanya edukasi, adanya sosialisasi terhadap masyarakat budaya hukum yang dapat tercapainya masyarakat yang tertib hukum. 


\section{DATIN}

Vol 1, No 2 Agustus - Desember 2020

\section{KESIMPULAN}

Sosiologi sebagai cabang ilmu yang mempelajari masyarakat dengan segala dinamikanya dan hukum hadir sebagai pengendali sosial tentang norma apa yang boleh dilakukan dan apa yang tidak boleh dilakukan dalam kehidupan bermasyarakat. Dalam ruang lingkupnya masyarakat memilki pranata sosial dan budaya dimana hukum menjadi pengendali untuk mewujudkan masyarakat madani dan beradab.

\section{DAFTAR PUSTAKA}

BUKU

Abdulsyani, 2012, Sosiologi Skematika, Teori dan Terapan, Bumi Aksara, Jakarta.

Budiman, Arief, 1996, Teori Negara, Kekuasaan dan Ideologi, Gramedia, Jakarta

Hermanto dan Winarno, 2011, Ilmu Sosial dan Budaya Dasar, Bumi Aksara, Jakarta
Iswara, Fred, 1964, Pengantar Ilmu Politik, Dwiwantara, Jakarta

Salman, Otje Dan Susanto,2004, F. Anton. Beberapa Aspek Sosiologi Hukum, PT. Alumni: Bandung

Soekamto Soerjono, Sosiologi Suatu Pengantar, Raja Grafindo Persada, Jakarta.

Soekanto, Sarjono, 1998, Pokok-Pokok Soisologi Hukum: PT. Raja Grafindo Persada: Jakarta

\section{JURNAL}

Iman Pasu Marganda Hardianto Purba, Penguatan Budaya Hukum Masyarakat Untuk Menghasilkan Kewarganegaraan Transformatif, Jurnal Civics, Vol. 14, Nomor 2, Oktober 2017

Santoso Agus, Kajian Hubungan Timbal Balik Antara Politik Dan Hukum

Tony Hanoraga, Dialektika Hubungan Hukum Dan Kekuasaan, 